\title{
Mobil Sağlık Uygulamalarının Hastanelerde Kullanılabilirliği: Hastane Yöneticileri Üzerine Bir Araştırma*
}

\author{
Hüseyin Demir ${ }^{1}$ Elif Türkan Arslan ${ }^{2}$ \\ ${ }^{1}$ Hacettepe Üniversitesi, İktisadi ve İdari Bilimler Fakültesi, Sağlık Yönetimi Bölümü, Sağlık Ekonomisi ve Politikası Anabilim Dalı \\ ${ }^{2}$ İzmir Kâtip Çelebi Üniversitesi, İktisadi ve İdari Bilimler Fakültesi, Sağlık Yönetimi Bölümü, Sağlık Ekonomisi ve Politikası Anabilim \\ Dal1
}

\begin{abstract}
Özet
Amaç: Mobil teknolojiler sağlık hizmetlerinde ortaya çıkan çoğu problem ile başa çıkmada bir araç olarak görülmektedir. Bu çalışmanın amacı, mobil sağlık uygulamalarının hastanelerde kullanılabilirliğini araştırmaktır. Yöntem: Çalışmada nitel araştırma yöntemi kullanılmıştır. Araştırmanın evrenini İzmir ilinde bir kamu hastanesinde çalıșan 18 üst ve orta kademe yöneticisi olușturmaktadır. Çalışmada amaçlı örnekleme yöntemlerinden kartopu örnekleme yöntemi kullanılmıştır. Araştırma, alanında uzman 2 kişinin görüşü alınarak hazırlanan 5 demografik soru ve 15 ifade ile gerçekleştirilmiştir. Araştırma, derinlemesine, bireysel, yarı yapılandırılmış yüz yüze mülakat tekniği kullanılarak 10 yönetici ile yapılmıştır. Verilerin analizinde Walcott'un 3 aşamadan olușan nitel veri analizi süreci benimsenmiștir. Bulgular: Araștırma sonuçlarına göre mobil sağlık uygulamalarının hastanelerde kullanılabilir bir araç olduğu saptanmıştır. Mobil sağlık uygulama kullanımının bazı dezavantajları olduğu da ortaya konmuştur. Mobil sağlık uygulama kullanımı için teknik ve hukuki alt yapının güçlendirilmesi, hasta bilgilerinin bu uygulamalar üzerinden akıșı önünde engel olușturabilecek her türlü unsurun elimine edilmesi ve tam bir güvenlik söz konusu olmadan hasta bilgilerinin bu uygulamalarda akışının problem yaratacağı saptanmıştır. Sonuç: Sonuç olarak, ülkemiz için mobil iletişim teknolojilerinin sunduğu firsatlardan yararlanılması için mobil sağlık uygulama kullanımına ilişkin pilot bölgelerin seçilmesi, elde edilen bulgular ışı̆̆ında gerekli düzenlemelerin yapılması, bu düzenleme ve girişimlerin Türkiye'de yaygınlaştırılmasının daha çağdaş sağlık hizmetleri için oldukça gerekli olduğu düşünülmektedir.
\end{abstract}

Anahtar Kelimeler: Mobil Sağlık, Mobil Sağlık Uygulamaları, Sağlık Hizmeti, Hastaneler.

\section{The Usability of Mobile Health Applications in Hospitals: A Research on Hospital Managers}

\begin{abstract}
Aim: Mobile technologies have been seen as a solution to many problems in healthcare. The study seeks to investigate the usability of mobile health applications in hospitals. Method: In our study, qualitative research method was used. The universe consists of 18 upper and middle-level managers working in a public hospital in İzmir. Snowboard sampling method was utilized. The research was carried out with the help of both 5 expressions to obtain the demographic findings and 15 expressions were prepared by taking the opinions of 2 experts in the field. Techniques conducted in the study are with in-depth, individual, semi-structured, face-to-face interviews had with 10 managers. Walcott's 3-step qualitative data analysis process was applied to data. Results: The results indicate that mobile health applications are usable for hospitals. The results suggest that there are some disadvantages of using mobile applications besides positive impressions. It can be put forward that strengthening the technical and legal infrastructure for the use of mobile applications will enable the flow of patient information with a complete security. Conclusion: As a result, it is considered that the selection of pilot regions for the use of mobile applications, making necessary arrangements in the light of findings, dissemination of these regulations, and initiatives in Turkey are necessary for more contemporary health services.
\end{abstract}

Key words: Mobile Health, Mobile Health Applications, Healthcare, Hospital.

*Bu çalışma İzmir Kâtip Çelebi Üniversitesi’nce Bilimsel Araştırma Projesi (BAP) olarak desteklenen ve 27.12.2016 tarihinde jüri önünde başarılı olarak savunulan "Mobil Sağlık Uygulamalarının Sağlık Hizmetlerine İşlem Maliyeti Yaklaşımı Bağlamında Etkisi: Hastane Yöneticileri Üzerine Bir Araştırma" adlı Yüksek Lisans Tezi'nden türetilmiştir.

\section{Giriş}

Mobil sağlık uygulamaları, son dönemde sağlık hizmetleri endüstrisinin dikkatini fazlasıyla çekmektedir (Kumar et al. 2013: 228). Elektronik sağlığın bir boyutu olarak ele alınan mobil sağlık (Gartner, 2009: 19), sağlık hizmetlerinin mobil iletişim teknolojileri ile sunumu olarak ifade edilebilir (Wragge ve Co, 2014: 7-11; Tezcan, 2016: 33). Sağl1k hizmetlerine talebin yüksek olmasından ötürü bu hizmete ihtiyaç duyan kişilere çoğu zaman cevap verilememesi sağlık sisteminin paydaşlarını problemi çözebilecek alternatif yollara yönlendirmektedir. Dünyada ve Türkiye'de kronik hastalıkların artış göstermesi, yaşlı nüfusun artışı ile birlikte sağlık hizmetine daha fazla ihtiyaç duyan insan sayısının artması vb. ile birlikte sağlık hizmetlerinin sunumuna yönelik yeni modeller gündeme gelmektedir. Bahsedilen durumlardan dolayı mobil sağlık uygulamaları sağlı sisteminin ve hastanelerin karşı karşıya kaldığı çoğu probleme yönelik bir çözüm olarak görünmektedir ki sağlık yöneticilerin yaklaşık olarak \%80’i (Ağaç, 2015) mobil iletişim teknolojilerinin sağlık hizmetlerinin sunumu için potansiyel bir araç olduğunu ifade etmişlerdir. Ayaktan ve yatarak tedavi alan hastaların uzaktan izlemi, vital bulgularının izlemi, hastaneye iletilmesi ve sağlık çalışanları ile zamanında paylaşılması gerek sağlık çalışanları gerekse de hastalar açısından oldukça önemli görünmektedir (Sloninsky, 2008: 17; Singh et al. 2014: 607; West, 2013: 6). Söz konusu uygulamalar sağlık çalışanlarına son derece esneklik vermesinin yanı sıra hastalara da kendi sağlık durumunu kontrol etme yönünde güç vermektedir ki bu durum mobil sağlığın temel hedefleri arasındadır (Pope et al. 2014; 121-122; Boston Consulting Group, 2012). Dolayısıyla sağlık sistemi açısından oldukça 
önemli bir araç olarak görünen mobil sağlık uygulamalarının Türkiye'deki hastanelerde kullanımının daha etkili sağlık hizmeti sunumu için son derece önemli olduğu ileri sürülebilir. Mobil sağlık uygulamalarının sağlık hizmetleri için çok sayıda faydası olmasına karşın söz konusu uygulamaların iyileştirmeye açık yönlerinin bulunduğunu söylemek mümkündür. $\mathrm{Bu}$ nedenle, mobil sağlik uygulamalarının hastane düzeyinde kullanılabilirliğini tüm yönleriyle ele almak oldukça hayatidir. Bu çalışmada mobil sağlık uygulamalarının hastane düzeyinde kullanılabilirliği araştırılmıştır.

\section{Mobil Sağlık Uygulamaları}

\subsection{Mobil İletisim Teknolojileri}

\subsubsection{Teknoloji}

Teknoloji, teknik veya süreç bilgisi; zihinsel ve bedensel çaba sarf edilerek pratik alana katkı sağlayan bir değerdir. Teknoloji, dünyada karşılaşılan problemlerin çözülmesi için kullanılan araç, gereç, makine, cihaz vb. 'ne atfedilmektedir. Daha geniş anlamda teknoloji, insan amaçlarının yerine getirilmesini sağlayan bir araçtır (Akgemci ve Güleş, 2010: 31). Teknoloji, kültürü biçimlendiren ve değiştiren bir mekanizma olarak görülmektedir; matematik, fizik, kimya, biyoloji vb. bilim alanlarında insanlığın faydasına olacak ve günlük hayata değer katacak bulguların hayata geçirilmesidir. Yeni geliştirilen bir cihaz, yeni bir paradigma, bir fikir, iş süreci, yeni bir yöntem, yeni bir teknik vb. olmasının yanı sıra teknoloji, insanlığın yararına olması planlanan gelișmelerin bütünüdür (Kılıç, 2016: 43-44; Enginoğlu, 2015: 27; Basalla, 2013: 17-18; Arthur, 2011: 136). Teknoloji aynı zamanda bilimsel uygulama ve araştırmalar sonucu ortaya çıkan icat ve yeniliklerdir (Tengilimoğlu ve ark. 2012: 97). Arthur (2011:122) teknolojiyi, eldeki amaca yeni veya farklı bir ilke uygulayan araç olarak nitelendirmektedir.

\subsection{Mobil İletişim Teknolojisi Kavramı}

Mobil iletişim teknolojileri, kişilerin sağlık statülerinin korunması, iyileştirilmesi ve geliştirilmesine yönelik kullanılan, kişisel ve paylaşılabilen teknolojik cihazlar olarak tanımlanmaktadır (Liu et al. 2011: 2032). Mobil iletişim teknolojileri olarak adlandırılan akıllı telefonlar, tabletler vb. teknolojik ürünler sadece iletişim ve sosyalleşme aracı olarak değil, çok çeşitli fonksiyonların icra edilebileceği cihazlar olarak tasarlanıp geliştirilmektedir. Geliştirilen multifonksiyonel mobil cihazlar, akıllı telefonlar, e-posta gönderme, alma, mesajlaşma, internette arama gerçekleştirme ve spesifik bir alana yönelik uygulama indirme özelliklerine sahiptir. Taşınabilir bir telefon ve aynı zamanda bir bilgisayar olan akıllı telefon, kișiye istediğini her zaman ve her yerde yapma olanağı sağlamaktadır. Sağlık otoriteleri tarafından değerlendirilen bu potansiyel, sağlık hizmetlerinin bu akıllı cihazlar üzerinden verilmesine olan inancı arttırmaktadır (Singh et al. 2014: 606). Mobil iletişim teknolojilere ilişkin yapılan sınıflandırma aşağıda gösterilmiştir (Sloninsky, 2008: 17; Singh et al. 2014: 607; West, 2013: 6).

\section{$\checkmark \quad$ Mobil telefonlar}

Sesli veya görüntülü olarak gerçek zamanlı iki yönlü iletişime olanak sağlayan ve çeşitli teknik fonksiyonları destekleyen bir araçtır.

\section{$\checkmark \quad$ Kișisel dijital danıșman ve akıllı telefonlar}

Kişisel dijital danışman, sağlık çalışanına klinik karar vermede kolaylık sağlayan bir araçtır. Akıllı telefon ise iki yönlü iletişime olanak sağlayan ve karmaşık nitelikte fonksiyonların yapılabildiği teknolojik üründür.

\section{$\checkmark \quad$ Hasta gözlem cihazları}

Hastaların sağlık durumuna ilişkin vital bulguların sağlık çalışanına iletilmesi için kullanılan teknolojik ürünlerdir.

\section{$\checkmark \quad$ Mobil tele-tıp / tele-hizmet cihazları}

Hastanın uzaktan izlemi, hastalığına teşhis konulması için kullanılan cihazlardır.

\section{Mobil öğrenme için MP3 oynatıcılar}

Bireylerde davranış değişikliği yaratılması yoluyla sağlık durumlarının iyileștirilmesi ve geliştirilmesi için kullanılan cihazlardir.

\subsection{Mobil Uygulamalar}

Mobil uygulama, mobil cihazların inovatif bir dönüşüm geçirerek geliştirilmesi ile akıllı cihazlara indirilebilen ve belli bir alana özgü olarak kullanılabilen yazılım olarak tanımlanmaktadır. Mobil uygulamalar, davranış değişikliği yaratmada ve kişilerin yanlış alışkanlıklarından dolayı geliştirdikleri sağlıklı olmayan davranışların iyileştirilmesi ve geliştirilmesinde stratejik bir araç olarak değerlendirilmektedir (Burke et al. 2012: 21; Singh et al. 2014: 606). Mobil uygulama, kişiye ait cihaz üzerinden appstore veya android gibi uygulama mağazalarında kullanıcıya ait bilgilerin girilmesi ve akıllı cihaza indirilip kullanılan bir yazılımdır (Bellman et al. 2011: 191; KamsuFoguem ve Foguem, 2014: 266; Liu et al. 2011: 2022). Mobil uygulamaların geliştirilmesi mobil iletişim teknolojilerinin oluşturduğu inovatif bir olgu olarak kabul edilmektedir (Singh et al. 2014: 606; Güler ve Eby, 2015: 47).

Mobil uygulamalar, ABD savunma bakanlığında hizmet veren askerlere geçirdikleri travmalar sonrası psikolojik eğitim verme amaçlı olarak geliştirilmiştir. Yani söz konusu uygulamaların ilk ortaya çıkışı, asker sağlığının psikolojik destek verilerek çeşitli tekniklerle geliştirilmesi amacına yöneliktir. Travmatik beyin hasarı olan askerlerin yaşadıkları olay sonrası solunum bozuklukları, sinir-endişe halleri ve stres hallerinin iyileştirilmesi amacıyla geliștirilmiştir. Buna yönelik geliştirilen mobil uygulamalar; ACT Coach, BioZen, Breathe2Relax, CBT-i Coach, ConcussionCoach, CPT Coach, LifeArmor, MindfulnessCoach, MovingForward, mTBI Pocket Guide, NavyLeaders Guide, 4 Coach, StayQuit, T2 MoodTracker, TacticalBreather ve Virtual Hope Box olarak belirtilmektedir (Luxton et al. 2014: 431).

\subsection{Mobil Sağlık Uygulamaları \\ 2.4.1. Mobil Sağlık Uygulaması Kavramı}

TÜSİAD'ın Mobil Sağlık Raporu'nda mobil sağlık, "toplumu bilinçlendirme, hastalıklar hakkında uyarılarda bulunma ve yönlendirme amaçlı SMS mesajlarından, görüntülü tele konsültasyon ve tele ziyaret uygulamalarına; cep telefonundan veya internet sitesinden randevu almaktan, taşınabilir veya giyilebilir cihazlardan tıbbi verilerin gönderilmesine; bireyin akıllı telefon uygulamaları ile kendine renk körlüğü testi uygulamasından, uzaktan kronik hastalık yönetimine kadar çok geniş bir yelpazede uygulama alanı bulmaktadır" olarak ifade edilmiştir (Tezcan, 2016: 33). Wragge ve Co (2014), sağlık alanında devrim niteliğinde değişimlerin yaşandığını ve sağlık hizmeti sunumunun geleneksel bir yapıdan bireysel ve hasta merkezli bir yapıya doğru evrildiğini belirtmiş olup bu doğrultuda mobil sağlığ 
sağlık hizmetlerinin, mobil iletişim cihazları ile dağıtımı olarak belirtmiştir. Mobil teknolojilerin sağlık hizmetleri alanında kullanımı yeni bir paradigma olarak ifade edilmiştir. Sağlık hizmetleri sunumunda yeni bir yöntem olan mobil sağlık, sağlık hizmetlerinin mobil teknolojiler ile sunumudur (Kumar et al. 2013: 228). Diğer yandan mobil sağlik, sağlık hizmetlerinin elektronik cihazlar üzerinden geliştirilen uygulamalar ile sunulması olarak da tanımlanabilir. Bilgi ve iletişim teknolojileri ve sağlı hizmetleri arasındaki ilişkiyi göstermekte kullanılan mobil sağlık kavramı, sağlık hizmetlerinin mobil ve giyilebilir cihazlar ile sunumu şeklinde de ifade edilebilir.

\subsubsection{Mobil Sağlık Uygulamalarının Gelişim Süreci}

Sağlık hizmetleri sunumunda özellikle ABD ve İngiltere gibi ülkelerde kullanılmaya başlanan mobil sağlık uygulamalarının gelişim sürecini belirtmek gerekmektedir ve bunu Şekil-1'de görmek mümkündür.

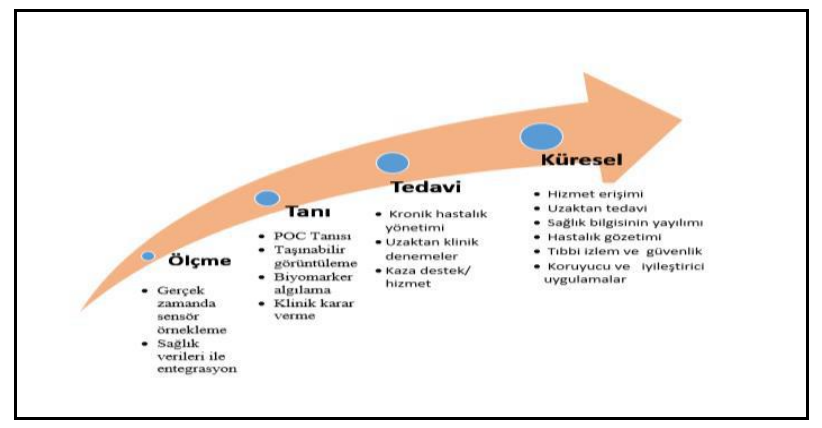

Şekil-1: Mobil Sağlık Uygulamalarının Gelişim Süreci

Kaynak: Kumar et al. (2013). Mobile Health Technology Evaluation, s. 229.

Şekil-1 incelendiğinde, mobil sağlık uygulamaları ile çok farklı işin yapılabileceğini söylemek mümkün görünmektedir. $\mathrm{Bu}$ uygulamalar ile gerçek zamanlı olarak hastanın bilgileri kolay bir şekilde elde edilebilmekte hasta ile sürekli irtibat halinde kalınabilmektedir. Hastanın bilgileri elde edildikten sonra tanısı konulabilmektedir. Hekim akıllı cihazı ile hastanın tetkik, radyolojik inceleme vb. sonuçlarını görüntüleyip hastalığa teşhis koyabilmektedir. $\mathrm{Bu}$ anlamda mobil sağlık uygulamalarının karar destek görevi gördüğü de söylenebilir. Hastanın tedavisine ilişkin olarak tanı konup tedavisine karar verildikten sonra mobil uygulama üzerinden hastanın sağlık durumu kontrol edilebilmekte, gerekli görüldüğü takdirde sağlık kurumuna yönlendirilebilmektedir. Daha geniş açıdan bakıldığında ise kronik hastalığa sahip hastaların takibi, hastalığın uzaktan denetiminin sağlanması, sağlık durumlarının geliştirilmesine yönelik olarak hastanın yönlendirilebilmesi de mobil sağlık uygulamaları ile yapılabilmektedir. Dolayısıyla mobil sağlık uygulamaları çokçeşitli fonksiyonları yerine getirebilmektedir. Bugüne kadar yaşanan gelişmelere bağlıolarak bu fonksiyonlar yerine getirilebiliyorsa, mobil sağlık uygulamaları ile yakıngelecekte daha karmaşık işlerin görülebileceği öngörülebilir.

\subsubsection{Mobil Sağlık Uygulamalarının Gerekliliği ve Kullanım Alanları}

Mobil uygulamalar, sağlık kurum ve kuruluşlarının merkeziliklerini azaltma yönünde hastalara esneklik sağlamaktadır. Kişi, acil ve müdahale gerektiren haller dışında, sağlık hizmeti almak için hastaneye gitmeyecek, bulunduğu yerden bu hizmeti alabilecektir. Bu olanak, sağlık hizmetleri sunumunda daha pratik olup, daha düşük maliyetli hizmet sunumuna imkân sağlamaktadır (Sloninsky, 2008: 20). Mobil sağlığın geliştirilmesinin nedenleri şöyle siralanmaktadır (Pope et al. 2014: 119; Mather et al. 2014: 8):

$\checkmark \quad$ Ortalama yaşam süresi uzamakta, buna bağlı olarak kronik hastalıklar artış göstermektedir.

$\checkmark \quad$ Yapılan harcamalara rağmen sağlık sistemindeki problemlere kalıcı çözüm bulunamamakta, hastalar gerektiği gibi takip edilememektedir.

$\checkmark \quad$ Sağlığın kişiselleştirilmesi gerekir. Sadece sağlık kurumu ve doktor merkezli bir anlayışın yerine hasta veya birey merkezli sağlık hizmetlerinin sunumu söz konusu olmalidir.

Mobil sağlık uygulamalarının kullanım alanlarını da şöyle sıralamak mümkündür (Velez et al. 2014: 189-191):

$\checkmark$ Hastaları belli davranışları yerine getirmede yönlendirebilir, bazı konulardahastalarda farkındalık yaratılabilir.

$\checkmark$ Hasta-doktor iletişiminin sağlanmasında kullanılabilir.

$\checkmark \quad$ Kaynaklara zaman ve mekân kısıtı olmaksızın erişim sağlanabilir.

$\checkmark \quad$ Hasta başında raporlama yapılabilir.

$\checkmark \quad$ Hastalığın uzaktan yönetimi sağlanabilir.

$\checkmark \quad$ Hasta eğitim programları düzenlenebilir.

$\checkmark \quad$ Profesyoneller arası iletişim sağlanabilir.

$\checkmark$ Mobil sağlı uygulamaları ile izlenebilecek hastalıklar diyabet, hipertansiyon, evde bakım, KKY, KOAH, Neoplazmik Hastallklar, Obezite, Postoperatif Hastalar, NöroDejeneratif Hastalıklar (Parkinson, Alzheimer vs.) olarak belirtilmekle birliktekanımızca bu hastalıkların sayısını arttırmak mümkündür.

\subsubsection{Mobil Sağlık Uygulamalarının Faydaları}

Mobil sağlık uygulamalarının kullanımı sonucu elde edilmesi öngörülen bazı yararlar şunlardır (Patrick et al. 2008: 178-180):

$\checkmark \quad$ Mobil sağlık uygulamalarının sağlık kurumlarında kullanılabilirliği sağlanır.

$\checkmark \quad$ Teknolojiyi kullanan doktorun verimliliği arttırılır.

$\checkmark$ Hasta ve hasta yakınlarının memnuniyet düzeyi arttırilır.

$\checkmark \quad$ Hasta ve hasta yakınlarının sağlık bilgisi düzeyleri arttırilır.

$\checkmark \quad$ Verilen hizmete bir geri ödeme bölümünün eklenmesi, böylece sağlık hizmetleri maliyetleri azaltılabilir ve finansmanı sağlanabilir.

$\checkmark$ Gizlilik, güvenlik ve mahremiyetin sağlanması, bununla ilgili kalıcı çözümlerin elde edilmesi sağlanabilir.

Mobil sağlık, sosyo-ekonomik bir etki yaratmasının yanında sağlık hizmetlerinin etkililiği ve verimliliğinin artmasında önemli bir role sahip olabilmektedir. Bunu dörtyolla görmek mümkündür (Franco ve Tursunbayeva, 2014):

$\checkmark \quad$ İyilik hali ve önleme: Kişilerin desteklenmesi, eğitim, farkındalık yaratma ve davranışların değiştirilmesi gibi araçlarla, kişilerin sağlık statülerinin iyileştirilmesi, hastalık insidansının düşmesini sağlama, böylece daha sağlıklı bir toplum yaratılabilir.

$\checkmark$ Teşhis: Hastalıkların erken teşhis edilmesi ve böylece hastalığın kişiler üzerindeki şiddetinin azaltılması, 
daha sonraki süreçlerde, hem hastayı hem de hastaneyi daha yüklü maliyetlerden kurtarmak.

$\checkmark$ Tedavi ve Gözlem: Hastaların mobil iletişim teknolojileri ile uzaktan takipedilmesi, hastaların hastaneyi ziyaret etmelerinin azaltılması sağlanabilir.

$\checkmark \quad$ Daha güçlü sağlık sistemi: Klinik karar verme geliştirilebilir, fiziksel ve beşeri kaynaklardan en üstün şekilde faydalanılabilir.

\section{Hastaneler}

\subsection{Hastanelerin Tanımı}

Hastaneler, Yataklı Tedavi Kurumları İşletme Yönetmeliği'ne (YTKIY) göre“"hasta ve yaralıların, hastalıktan şüphe edenlerin ve sağlık durumların kontrolettirmek isteyenlerin, ayakta veya yatarak müşahede, muayene, teşhis, tedavi ve rehabilite edildikleri, aynı zamanda doğum yapılan kurumlar" olaraktanımlanmaktadır (YTKIY, Madde 4). Ağırbaş (2016: 16) ise hastaneleri "ekonomik, verimli ve etkili olarak her türlü sağllk hizmetinin kesintisiz üretildiği, e ̌̆itim, araştırma ve toplum să̆lı̆̆ hizmetlerinin yürütüldüğü, çevreden etkilenen ve çevreyietkileyen, karmaşık, pahalı ve kendine özgü özellikleri olan ve profesyonel yönetimgerektiren sosyal kurumlar" olarak tanımlamıştır. Hastaneler, fonksiyonları gereğiteknolojiden önemli ölçüde yararlanan hizmet birimleri; sağlık hizmetleri içerisindekivazgeçilmez yeri önemi, ileri teknoloji gereksinimi, yüksek maliyetler ve profesyonelpersonel istihdamı vb. nedenlerle modern ișletmecilik anlayıșı ile yönetilmesi gereklikurumlardır (Esatoğlu ve Köksal, 2010: 233). Diğer bir deyişle hastaneler, muayene, teşhis, tedavi ve rehabilite edici sağlık hizmetlerinin sunulduğu, hastaların uzun veyakısa süreli tedavi gördükleri kuruluşlardır. Hastaneler, hizmet üretim kapasitesi vesağlık harcamaları bakımından sağlık sisteminin en önemli alt sistemidirler (Kavuncubaşı ve Yıldırım, 2012: 118).

Hastaneler birer açık sistemdir. Çevre ile etkileşim içerisinde olan, faaliyetlerini sürdürmek için çevreden kaynak temin etmek zorunda olan bu yapılar, girdileri çıktılara dönüştürerek dinamik denge halini korumaktadır. Hastanenin girdileri, insan gücü, hasta, malzeme, teknoloji, bilgi ve sermayedir. Çıktılar ise, hasta ve yaralıların tedavi edilmesi, toplum sağlığının yükseltilmesine katkıda bulunmak, eğitim ve araştırma faaliyetlerini yürütmek, klinik eğitimler vb. 'dir. Girdilerin çıktılara dönüşmesini sağlayan süreçler ise, hastane yönetiminin planlama, organizasyon, koordinasyon, yürütme ve kontrol fonksiyonlarından oluşmaktadır (A ğırbaş, 2016: 21).

Teknoloji ve tıp biliminde yaşanan gelişmeler, hastaneleri hızla değiştirerek önemini arttırmıştır. Daha fazla işlevsellik kazanan hastaneler, ülkenin sağlık harcamalarının büyük bir kısmının gerçekleştiği sosyo-ekonomik kurumlar olması nedeniyle daha fazla önem kazanmıştır. Ülkenin önemli miktardaki kaynaklarının bu kurumlarda harcanmaya başlanması, hastane sektörüne dikkatlerin çekilmesine sebebiyet vermiş bu kurumların yakından incelenmesini sağlamıştır (Coye ve Kell, 2006: 167; Tengilimoğlu ve ark., 2012: 97). Bu konuda Drucker (2013a: 35), daha iyi hasta bakım hizmetini daha ekonomik şekilde verecek bir hastanenin önemine dikkat çekmiş ve ileri teknolojinin bu amaç için oldukça etkili olabileceğini belirtmiştir.

\subsection{Sistem Olarak Hastaneler}

Hastanelere daha geniş açıdan bakıldığında, bu yapıların sadece sağllk hizmeti sunma görevi değil, diğer birçok görevin de icra edildiği yerler olmaları oldukça dikkat çekicidir. Hastanelerde sadece tıbbi hizmet sunulmamakta, tıbbi hizmetlerin yanı sıra, otelcilik, yemekhane, güvenlik vb. hizmetler de sunulmaktadır. Her sistem belirli bir çevrede faaliyetlerini sürdürmektedir. Bir sistem, çevresi ile bilgi, kaynak, materyal ve enerji alışverişinde bulunuyorsa açık sistemlerdir. Hastaneler de birer açık sistem olarak çevre ile yakın etkileşim içerisindedir. Hastanede çalışan sağlık personeli, kullanılan teknoloji, tıbbi cihazlar, malzemeler vb. tüm faktörler hastanelerin çıktı olarak sağlık hizmeti üretmesi için olmazsa olmaz nitelikte kaynaklardır. Hastaneler bu kaynakları kullanarak çevreye sağlık hizmeti sunar ve toplumun sağlık statüsünün geliştirilmesine katkıda bulunur (Ağırbaş, 2016: 16). Hastane sistemine ilişkin genel çerçeve Şekil-2'de gösterilmiştir.

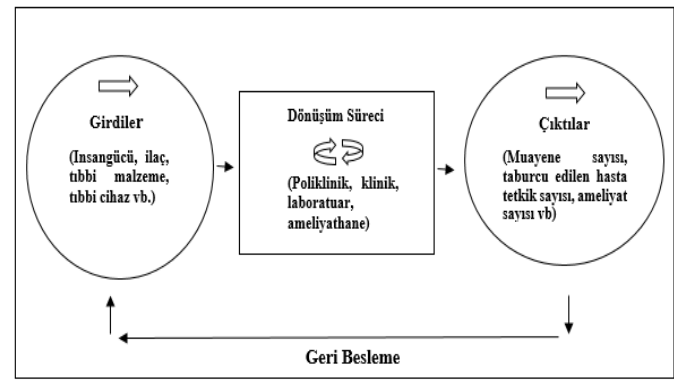

Şekil-2: Hastane Sistemi

Kaynak: Ağırbaş, İ. (2016). Hastane Yönetimi ve Organizasyon, s. 21.

Şekil-2'den görülebileceği üzere hastaneler, sağlı hizmeti üretmek için çevre ile etkileşim içerisindedir. Çevreden personel, kaynak, enerji tedarik ederek bunları kendi bünyesinde dönüştürüp çevreye çıktı olarak sunmaktadır böylece çevreden aldığı geri bildirimler ile faaliyetlerini kontrol etmektedir (Ağırbaş, 2016: 21). Hastaneler diş çevreden oldukça etkilenmektedir. Ülkedeki sağlık politikası, sağlık organizasyonu, sağlık hukuku, eğitim ve personel politikası, finansal kaynaklar vb. faktörler hastanelerin işleyişi üzerinde önemli etkiye sahiptir. Daha geniș açıdan bakılacak olursa, yasal sistem, kültürel düzey, refah düzeyi, hükümet politikaları ve politik sistem hastanelerin etkilendiği diğer faktörlerdir (Tengilimoğlu ve ark. 2012: 96).

\subsection{Hastanelerin Temel Özellikleri}

Hastaneler esasen sağlık hizmeti sunmak üzere örgütlenmiş kurumlardır. Tıbbi kuruluş özelliği gösteren hastaneler, çok farklı nitelikte girdilerin kullanılması ile sağlık hizmeti üretme rolünün yanında diğer birçok rolü de üstlenmektedir (Djellal ve Gallouj, 2007: 181). Hastanelerin temel özellikleri şunlardır (Kavuncubaşı ve Yıldırım, 2012: 134-137):

$\checkmark \quad$ Çıktının tanımlanması ve ölçümü güçtür.

$\checkmark \quad$ Sağlık kurumlarında yapılan işler oldukça karmaşık ve değişkendir.

$\checkmark \quad$ Sağlık kurumlarında gerçekleştirilen etkinliklerin büyük kısmı acil ve ertelenemez niteliktedir.

$\checkmark$ Yapılan işler hata ve belirsizliklere karşı oldukça duyarlıdır ve tolerans gösteremez. 

yüksektir.

Sağlık kurumlarında uzmanlaşma seviyesi çok

$\checkmark$ Sağlık kurumlarında işlevsel bağımlılık çok yüksektir. $\mathrm{Bu}$ nedenle farklı meslek gruplarının faaliyetleri arasında yüksek düzeyde eş güdüm gereklidir.

$\checkmark$ Hastaneler başta olmak üzere tüm sağl1k kuruluşlarında ikili otorite hattı bulunmaktadır. Bu durum eş güdümleme, denetim ve çatışma gibi sorunlara yol açmaktadır.

$\checkmark \quad$ Sağlık kurumlarında insan kaynakları profesyonel kişilerden oluşmaktadır ve bu kişiler kurumsal hedeflerden daha çok mesleki hedeflere önem vermektedir.

$\checkmark$ Hizmet miktarını ve sağlık harcamalarının önemli bir bölümünü belirleyen hekimlerin faaliyetleri üzerinde etkililiği yüksek olan yönetsel ve kurumsal denetim mekanizması kurulamamıştır.

Hastaneler, organizasyon açısından ele alındığı zaman özellikleri aşağıda belirtildiği gibi sıralanabilir (Seçim, 1991: 19-27).

$\checkmark \quad$ Hastaneler birer hizmet organizasyonudur.

$\checkmark$ Hastaneler karmaşık yapıda, açık-dinamik sistemlerdir.

$\checkmark$ Hastaneler matriks yapıda faaliyet gösteren organizasyonlardır.

$\checkmark$ Hastaneler günde 24 saat hizmet veren organizasyonlardır.

$\checkmark$ Hastaneler personelinin önemli bir kısmı bayanlardan oluşan organizasyonlardır.

\subsection{Hastanelerin İşlevleri}

Hastanelerin dört temel işlevi bulunmaktadır (Ağırbaş, 2016: 16; Kavuncubaşıve Yıldırım, 2012: 118):

$\begin{aligned} \checkmark & \text { Tedavi hizmetleri } \\ \checkmark & \text { Koruyucu ve geliştirici sağlık hizmetleri } \\ \checkmark & \text { Eğitim } \\ \checkmark & \text { Araştırma }\end{aligned}$

Tedavi hizmetleri, hastanelerin en eski ve en temel işlevidir. Hastanelerin temel yeteneği sağlık hizmeti üretmektir. Hastaneler, hasta ve yaralılara ve aynı zamanda doğum yapacak olan kişilere, ayaktan ve yatarak tanı ve tedavi hizmetleri sunan kurumlardır. Hastaneler, tedavi hizmetlerinin yanı sıra, koruyucu ve geliştirici sağlık hizmetlerinde de önemli rol oynamaktadır. Örneğin, sigara veya alkol bağımlılığı olan kişilere bu kötü alışkanlıkları terk etmeleri için tedavi hizmetleri verilebilmekte, bu kötü alışkanlıklara karşı mücadele edilebilmektedir. Hastaneler, eğitim hizmetlerinin yürütüldüğü kurumlar olarak da öne çıkmaktadır. Hastane personelinin hizmet içi eğitimi, öğrencilerin eğitimi, toplumun eğitimi ve hasta ve yakınlarının eğitimi verilen eğitimlerin en önemlileridir. Hastanelerin bir diğer önemli işlevi araştırmadır. Hastaneler, tıp bilimleri alanında araştırmaların yapıldığı merkezlerdir. Eğitim ve araştırma hastaneleri ve üniversite hastaneleri, araştırmaların en çok yoğunlaştığı merkezlerdir (Kavuncubaşı ve Yildırım, 2012: 118-119).

\section{Konuya İliş̧kin Literatür}

Sağlık İstatistik Yıllığı 2013 Raporu'na göre Türkiye'de 2013 yılında bir kişi herhangi bir sağlık kurumuna ortalama 4,9 defa müracaat etmiştir. Müracaat edilen sağlık kurumları Sağlık Bakanlığına bağlı 1 . ve 2. basamak sağlık hizmeti veren yapilardır. Ortalama olarak ifade edilen bu rakam bölgelere göre değişmekle birlikte önceki yıllara göre artış göstermiş̧ir. Yaşanan bu artışlar sağlık tesislerinin iş yükünün artışı, aşırı kaynak kullanımına dolayısıyla maliyetlerin düzensiz olarak artmasına sebep olmaktadır (Sağlık İstatistik Yıllığı, 2013). Dolayısıyla sağlık hizmetlerinde mobil iletişim teknolojilerinin kullanılması söz konusu problemlerin çözümünde etkili olacağı ileri sürülebilir. Burke et al. (2012), kişinin öz yönetiminde kilo yönetimine olanak sağlayan mobil uygulamaların geliştirilmesini, kişilerin sürekli olarak takip edilmesi ayrıca kişinin de kendisini her gün düzenli olarak takip edip kontrol etmesini daha bilinçli ve sağlıklı bireylerin yetiştirilmesinde önemli bir araç olarak görmektedir. Wu et al. (2014) ve Wu ve Hommel (2014), akıllı telefonların gelişimi ve kullanımıla birlikte poliklinik hizmetlerinde sms kullanımının önemi üzerinde durmuşlardır. Nakamura et al. (2014: 16), meta analizini yöntem olarak kullandıkları çalışmalarında, kronik kalp krizi hastalarının uzaktan gözlenmesinin sağlık sonuçları üzerindeki etkisini araştırmışlardır. Çalışma sonucunda, kronik kalp hastalığ olan hastaların sağlıklarının uzaktan hasta gözlemi yoluyla iyileştirilebileceği sonucuna varmışlardır. Al-Hadithy ve Ghosh (2013), akıllı telefon kullanımının plastik cerrahi üzerindeki etkilerini araştırmışlardır ve çalışma sonucunda söz konusu akıllı cihazların potansiyel olduğunu ortaya koymuştur. Semple et al. (2015), 65 hasta üzerinde mobil uygulama kullanımının etkilerini araştırmıştır. Çalışmada, göğüs ve ortopedi ameliyatı sonrası hastaların izlenmesinde mobil uygulama kullanımı yoluna gidilmiştir. Hastalardan 30 gün boyunca ameliyat sonrası durumları ile ilgili bilgiler ve ameliyat bölgesinin fotoğraflarının çekip uygulamaya yüklenilmesi istenmiştir. Araştırma sonucunda, mobil uygulama kullanımının cerrahlara esneklik sağladığını ve kabul edilebilir olduğu, gelişmesi olası komplikasyonlara erken müdahale imkânı sağlayabilmesi bakımından postoperatif dönemde hastaların gözleminde yeni bir çözüm olabileceği belirtilmiş̧ir.

Hastanelerde mobil sağlık uygulamalarının kullanımına yönelik Işsk ve Güler'in (2010) çalışması oldukça önemlidir. Söz konusu çalş̧̧ada mobil iletişim imkânlarının olanak sağladığı tele-tıp ile hastanelerin teşhis merkezi olmaktan çıkabileceğini ve sadece müdahale yeri haline gelebileceği belirtilmektedir. Diğer yandan The Economist İntelligence Unit (2015), Amerika'da Arizona eyaletinde kırsal alanda yaşayan 50 kişi üzerinde mobil cihaz tabanlı 3 olaylık bir periyotta gözlem gerçekleştirmiştir. $\mathrm{Bu}$ gözlemler, nabız ölçme, oksijen seviyesi, tansiyon ve kilo ölçümlerini kapsamaktadır ve bu bilgiler direkt olarak sağlık sunucusuna iletilmektedir. Üç ay sonunda, kişi başına hastanede geçirilen süre 5 ile 14 gün arasında azaltılmış ve kişi başı 90.000 dolar tasarruf edildiği tespit edilmiştir. The Economist İntelligence Unit (2015), Çin'de kalp sağlığı için kablosuz sağlık programını başlatmış ve kardiyovasküler hastalığı olan 1100 kişiye mobil cihaz vererek bunları belli bir süre izlemiştir. $\mathrm{Bu}$ çalışma ile sağlık hizmetlerine eşit bir şekilde erişimin sağlandığı ve sadece kalp sağlığı ile ilgili hizmetlerde değil tüm sağllk hizmetlerini kapsayan mobil uygulamaların geliştirilmesi gerekliliği üzerinde durulmuştur.

Dünya Sağlık Örgütüne bağlı ülkelerin hemen hemen hepsinde mobil sağlık projelerinin uygulandığını söylemek mümkündür. ABD, Danimarka, İngiltere, İsveç, Hindistan, Angola, Malezya gibi ülkelerde sağlı hizmetlerinde çok 
çeşitli amaçlarla mobil sağlık uygulamaları kullanılmaktadır. Tüberküloz hastalarının ilaç alımlarının izlemi için Pakistan'daki Out TB ve Nikaragua'daki X out TB projeleri; annelerin cep telefonu kullanarak sağlık merkezleri ile sürekli irtibatta olmalarını sağlamaya yönelik Tanzanya'daki WiredMothers projesi; HIV/AIDS tedavisinde düzenli ilaç alımı ve randevulara uymaya ilişkin sms gönderimine dayanan Meksika'daki VidaNET projesi; cep telefonları ile sıtma tedavisine ilişkin ilaçların stok durumlarını kontrol etmeye yönelik Tanzanya ve Gana'daki SMS for Life projeleri; Vietnam'da yaşayan insanların cinsel yaşam ve üreme sağlığına ilișkin eğitim ve farkındalık yaratma amaçlı Reaching Hard-to-Reach Populations projesi; HIV/AIDS teşhis ve tedavisiyle ilgili sağlık çalışanlarının hastaya ait bilgileri cep telefonu ile sisteme girmesini sağlamaya yönelik Ruvanda'daki Phonesfor Health projesi uygulanan mobil sağlık projelerinden birkaçıdır (Tezcan, 2016: 85-89).

Türkiye'de de mobil sağlık uygulamalarının kullanımına yönelik önemli girişimler olduğu söylenebilir. Acil hizmetlerde mobil veri aktarımını sağlamaya yönelik Wimax Ambulans Pilot projesi; uzaktan teletıp hizmetini sunmaya yönelik Adıyaman Teletıp Pilot projesi; sağlık portal ve mobil uygulama platformu niteliğinde olan Sağlık 365 projesi; mobil mesaj ile bilgilendirme amaçli Turkcell Bebeğimi Beklerken/Büyürken projesi; sms ile uyarma amaçlı Turkcell Diyet projesi; uzaktan teletıp hizmeti sağlamaya yönelik Sağlikmetre projesi; sms ile uyarma, kronik hastalık takibi amaçlı Doro Kolay Telefon Mobil İlaç Hatırlatma projesi; uzaktan teletıp hizmeti sunma amaçlı Sağlık Takipçim, Mobil Tahlil, Avea-Acıbadem Kronik Hastalık Yönetimi, Ankara Yaşam Destek Merkezi ve Uzaktan Güvenli Hasta Takibi projeleri; mobil pazarlama amaçlı Tabletle İlaç Pazarlaması projesi; mobil mesaj ile bilgilendirme amaçlı Avea Anne Oluyorum ve Avea Bebeğim Büyüyor projeleri; telekonsültasyon amaçlı Avea Alo Doktorum ve Türk Telekom Videofon Klinik projeleri; MHRS mobil, Mymediks Kişisel Sağlık Takip Sistemi ve Sağlık Artı projeleri mobil sağlık uygulamalarına ilişkin Türkiye'de uygulanan projelerden birkaçını oluşturmaktadır (Tezcan, 2016: 85-96).

\section{Materyal ve Metot}

\subsection{Amaç ve Önem}

$\mathrm{Bu}$ çalışmanın temel amacı, mobil sağlık uygulamalarının hastanelerde kullanılabilirliğini araştırmaktır. Mobil sağlık uygulamalarının hastane düzeyinde incelendiği bu çalışmanın sonucunda sağlık hizmetlerinin önemli paydaşları niteliğinde olan hastane yöneticilerinin mobil sağlık uygulamalarının hastanelerde kullanımının yararlı ya da iyileştirmeye açık yönlerini ortaya koymaları, buna yönelik çözüm önerileri getirmelerine ilişkin görüş belirtmeleri sağlanmış olacaktır. Dolayısıyla doğrudan söz konusu uygulamaların yönetim faaliyetlerini gerçekleştirecek ve bunların sonuçlarından etkilenecek kişilerin konuya ilişkin görüşleri ve tutumları saptanmış olacaktır. Bu durum çalışmanın önemli yanını oluşturmaktadır. Çalışmanın beklenen faydaları, bu konudaki literatüre katkı sağlamak, mevcut boşluğu doldurmak, mobil sağlık uygulamalarının hastanelerde kullanılabilir olup olmadığına vurgu yapmak ve konunun önemine dikkat çekmektir.
Araştırmanın problem cümlesi, "mobil sağlık uygulamaları hastanelerde kullanılabilir mi?" olarak belirlenmiştir.

\subsection{Evren ve Örneklem}

Araştırmanın evrenini T.C. Sağlık Bakanlığı İzmir Tepecik Eğitim ve Araştırma Hastanesi'nde çalışan 18 üst ve orta kademe yöneticisi oluşturmaktadır. Araştırmanın bu hastanede yapılmasının nedeni, söz konusu hastaneye ait mobil uygulamanın olması ve hastanenin çeşitli amaçlarla mobil uygulamayı aktif olarak kullanmasıdır. İzmir Kâtip Çelebi Üniversitesi'nden etik kurul onayı ve İzmir İli Kamu Hastaneleri Birliği Kuzey Genel Sekreterliği’nden ise hastanede araştırma yapılabilmesi için gerekli izin sağlanmıştır (25 Ocak-25 Haziran 2016). Bu çalışmada, amaçlı örnekleme yöntemlerinden biri olan kartopu (zincirleme) örnekleme yöntemi kullanılarak örneklem belirlenmeye çalışılmıştır. Kartopu örnekleme yöntemi, araştırmacının problemine ilişkin olarak zengin bilgi kaynağ olabilecek birey veya durumların saptanmasında etkilidir. Araştırma konusu ile ilgili kimlerin bilgi sahibi olduğu ve kimlerle görüşme yapılması gerektiğini vurgular. Araştırma süreci ilerledikçe elde edilen isimler veya durumlar kartopu gibi büyümeye devam eder, belirli bir süre sonra görüşülmesi gereken birey veya ilgilenilmesi gereken durum sayıs azalmaya başlar (Yıldırım ve Şimşek, 2013: 139). Olasılıklı olmayan bütün örneklem tekniklerinde olduğu gibi amaçlı örnekleme tekniğinde de katılımcıların benzer niteliklere (demografik özellik, tutum, deneyim) sahip olmaları araştırmanın sonuçları üzerinde oldukça etkilidir. Araştırmanın amacına daha uygun özellikler taşıdıkları için görüşmeler 10 yönetici ile yapılmıştır. Araştırmanın üst/orta kademe yöneticileri ile yapılmasının nedeni, söz konusu yöneticilerin kaynakları kullanmaya yetkili olmaları ve aynı zamanda mobil sağlık uygulamaları ile ilgili bilgi sahibi kişiler olmalarıdır. Hastane yöneticilerinin bu alanda edindikleri tecrübe ve bilgi birikimlerinden faydalanılmasının araştırmanın sonuçlarına doğrudan katkı sağlayacağı düşünülmüştür. Bunun sonucunda alana katkı sağlayabilecek daha gerçekçi sonuçların elde edilmesi hedeflenmiştir.

\subsection{Teknik ve Yöntem}

$\mathrm{Bu}$ çalışma, nitel araştırma türündedir. Nitel araştırmalar bir olayın veya durumun asıl doğasını anlamak için ve araştırmacıyı kesin sonuçlara götürmeyen, ele alınan ortam içerisinde değerlendirilen araştırmalardır. Nitel araştırma yöntemi, nicel araştırma yöntemi kullanımının uygun olmadığı çalışmalarda kullanılan bir yöntemdir (Yıldırım ve Şimşek, 2013: 45-47). $\mathrm{Bu}$ çalışmada nitel araştırma yönteminin kullanılmasının temel nedeni, mobil sağl1k uygulamalarının Türkiye'de henüz çok yeni bir alan olması ve mobil sağlık hizmetlerine ilişkin tutumun anket yöntemi ile araştırılmasının istenilen sonuçların elde edilmesinde kısıtlar oluşturabilme ihtimalidir. Ayrıca, mobil sağlığın sağlı hizmetlerine etkisinin en iyi şekilde değerlendirilebilmesi ve daha gerçekçi sonuçlar elde edilmesi, doğal ortam içerisinde bir başka deyişle olayların geçtiği veya ișin bizzat yapıldığı yerde buna ilișkin araştırmanın yapılması bu çalışma için oldukça önemlidir. Bu durum araştırmanın geçerliğini arttırmada önemli etkiye sahiptir.

Araştırmada veri toplama aracı olarak geliştirilen bir "görüşme formu" kullanılmıştır. Görüşme formu, yapılan 
literatür taraması sonuçlarına dayanarak ve alanında uzman iki kişinin de görüşü alınarak hazırlanan 5 demografik soru ve 15 ifadeden oluşmaktadır. $\mathrm{Bu}$ çalışmada yüz yüze görüşme/mülakat yöntemi kullanılmıştır (Gürbüz ve Şahin, 2014: 380). Derinlemesine-bireysel, yarı-yapılandırılmış, yüz yüze mülakat tekniği ile yapılan 30 dakikalık görüşmelerde her katılımcının sorulara kendisinin yazarak cevap vermesi sağlanmıștır. Bu amaçla, araştırmacının araştırma süreci boyunca tarafsızlığı ve katılımcının ifade etmek istediklerini doğrudan aktarabilmesi hedeflenmiştir.

Nitel verilerin analizinde araştırmacı merkezi konumdadır. Araştırmacı, çeşitli yöntemlerle elde ettiğ verileri kaydeder, düzenler, tasnif eder, sentezler bunlara bağlı olarak çeşitli örüntüler elde eder ve elde ettiği bu bulguları raporlaştırır. Özellikle son yıllarda nitel veri analizine oldukça önem verilmektedir. Ancak nitel veri analizlerinin nasıl yapılacağına ilişkin üzerinde fikir birliğine varılan herhangi bir model yoktur. Genel kabul görmüş bir modelin olmamasına karşın elde edilen nitel verinin nasıl analiz edilebileceğine ilişkin öneriler bulunmaktadır (Gürbüz ve Şahin, 2014: 383). Bu çalışmada Walcott'un (1994) nitel veri analizi önerisi benimsenmiștir. Walcott, nitel veri analizi için temel olarak 3 aşamalı bir model önermektedir. Bunlar; betimleme, analiz ve yorumlama esasına dayanmaktadır. Betimleme, katılımcıların ifadelere verdiği cevapların doğrudan sunulması; analiz, bulgularda gizli kalan unsurların açığa çıkarılması, fikir birliği ve fikir ayrılığı olan noktaların okuyucuya sunulması; yorumlama ise araştırmacının bu iki aşama sonucunda tümevarımcı bir yaklaşımla bulgulara anlam kazandırma veya kuram oluşturma sürecidir (Walcott, 1994). Bu nedenle bu çalışmada, verilerin analizinde ilk olarak katılımcıların her bir soruya verdikleri cevaplar okuyucuya doğrudan sunulmuş ve irdelenmiştir. Daha sonrasında ise bulgular yorumlanmış ve birtakım çıkarımlarda bulunulmuştur.

\subsection{Araştırmanın Kısıtlılıkları}

Araştırmaya dâhil edilen yönetici sayısının az olmasına ek olarak mobil sağlık uygulamalarının Türkiye'de oldukça yeni olmasından ötürü yöneticilerin konu ile ilgili detaylı bilgiye sahip olmaması araştırmanın temel kısıtlarını oluşturmaktadır.

\section{Bulgular}

\subsection{Katılımcıların Kişisel Özelliklerine İlişkin Bulgular}

Katılımcılar üst ve orta kademe yöneticilerinden oluşmaktadır ve bunların 8'i erkek 2'si ise kadın yöneticidir. Katılımciların 3'ü 36-42, 4'ü 43-48 ve 3'ü de 49 ve üstü yaş aralığındadırlar. Katılımcıların 1'inin çalışma süresi 1-5 yıl, 2'sinin 6-10 yıl 3'ünün 11-15 y1l ve 4'ünün ise 16 yıl ve üzeri olmakla birlikte tamamı evli olduklarını belirtmişlerdir. Katılımciların 3'ü 3500-4000 TL, 4'ü 4001-4500 TL ve 3'ü ise $4501 \mathrm{TL}$ ve üzeri gelire sahiptir.

\subsection{Araștırmaya İlişkin Bulgular}

Araştırmaya ilişkin bulgular aşağıda belirtilmiştir.

i. Mobil iletişim teknolojileri hastane bilgi yönetim sistemleri ile entegre çalışabilir mi buna yönelik ne yapılmalıdır?

Araştırma kapsamında birinci soruya verilen cevaplar incelendiğinde, bütün katılımcıların, mobil iletişim teknolojilerinin hastane bilgi yönetim sistemi ile entegre çalışabileceği konusunda hemfikir oldukları görülmektedir. Mobil iletişim teknolojilerinin hastanenin kullandığı bilgi sistemine kolayca entegre edilmesinin mümkün olduğu anlaşılmaktadır. Tüm katılımcıların mobil teknolojilerin entegre edilerek kullanılmasına ilişkin fikir birliğinin yanı sıra Katılımc1 1'in özellikle bu teknolojilerin hastane sistemine entegre edilmesi gerektiğini vurgulaması dikkat çekicidir. Ayrıca söz konusu katılımeı bunun iki adımlı olması gerektiğini önermiştir. Kișilere sadece sağlık hizmeti sunma amaçlı cihazların verilmesi ve kişilerin kendi kullandıkları akıllı cihazların da hastane bilgi sistemine entegre edilerek hizmet sunumunun daha da iyileştirilmesi gerektiğini ileri sürmüștür. Üzerinde hemfikir olunan bir başka durum da mobil sağlık sistemi alt yapısının iyice oluşturulması gerektiğidir. Katılımcıların hemen hemen tamamı mobil sağlık alt yapısının sağlam ve en iyi şekilde oluşturulması gerektiğini savunmaktadır. Hasta bilgilerinin mahremiyeti söz konusu olduğu için gizlilik ve güvenlik alt yapısına ilişkin iyi bir sistemin oluşturulması gerektiğini savunmuşlardır. Bu duruma ilişkin Katılımeı 9'un mobil sağlığın hukuki alt yapısının iyice oluşturulmasına yönelik bir tartışma zemini sağlanmasının gerekliliğini vurgulaması da önemlidir. Ayrıca Katılımcı 10'un ülkemizde özellikle bilişim alt yapısına ilişkin yaşanan problemlerden yola çıkarak teknolojik sistemlerin yetersizliğini değerlendirmesi de öne çıkan bir diğer görüştür. Bu anlamda hayati niteliğe sahip olan mobil sağlık hizmetlerinde problemlerin yaşanmaması ve hasta bilgilerinin korunmasının sürdürülebilirliği noktasında başarının sağlanması için iyi bir alt yapının oldukça önemli olduğu ortaya çıkmaktadır.

\section{ii. Bulut bilişim teknolojisi üzerinden sunulan sağlık hizmetleri ne kadar güvenlidir, buna yönelik neler yapılabilir?}

Katılımcıların bulut bilişim sistemlerinin güvenliğine ilişkin algılarının olumsuz yönde olduğunu söylemek mümkündür. Katılımcıların tamamı bulut sistemler üzerinden sağlık hizmetlerinin sunumunun güvenli olmayacağını belirtmișlerdir. Bulut bilișim sistemlerinde hasta bilgilerinin depolanması ve yönetilmesinin gizlilik ve güvenlik açısından riskler taşıdığı konusunda katılımcılar fikir birliği içerisindedir. Ancak bulut sistemlerin güvenlik problemine ilişkin Katılımcı 1'in ifadesi dikkat çekicidir. Katılımcı 1 hiçbir sistemin tam bir güvenlik içerisinde olmasının mümkün olmadığını ifade etmiş ve tam bir güvenlik alt yapısı bulunmamakla birlikte bulut sistemlerin sağllk hizmetlerinde kullanılabileceğini ifade etmiştir. Her bir sistemde hata ve kısıtlar olduğunu ifade ederken mobil bankacılığa da işaret etmektedir. Mobil bankacılık üzerinden paranın yönetildiği bir dönemde sağlık bilgilerinin de esnek bir yapıya kavușturulması gerektiğini belirtmiștir. Mobil bankacılık hizmetlerinin yaygın olduğunu belirten Katılımcı 1, güvenlik alt yapısına ilişkin alternatif yollar önermiştir. Diğer yandan Katılımcı 6, bulut sistemlerin kullanılan bazı yöntemlerden daha güvenilir olduğunu belirtmekle birlikte tam bir güvenliğin söz konusu olmadığını ifade etmiştir. Daha güçlü bir güvenlik alt yapısı için de Sağlık Bakanlığı'nın bu konuda güçlü yazılımlar geliştirmesi ve güvenlik alt yapısını kurması gerektiği katılımcıların çoğunluğu tarafindan belirtilmiştir. Özetle, bulut bilişim teknolojilerinin sağlık hizmetleri sunumunda güvenli görülmediği ancak yine de kullanılması gerektiği yönünde bir eğilim olduğu söylenebilir. 
iii. Mobil iletişim teknolojileri ile sağlık hizmetlerinin sunumu için hastane düzeyinde bulut bilişim sistemlerinin altyapısı nasıl oluşturulmalıdır?

Katılımcıların bulut bilişim sistemlerinin hastane düzeyinde yapılandırılmasının nasıl olması gerektiğine yönelik verdikleri cevaplar incelendiğinde, bulut sistemlerin alt yapısının Bakanlık düzeyinde yapılandırılması ve Bakanlığın tüm güvenlik altyapısını sağlaması gerektiği düşüncesinin yaygın olarak kabul edildiği anlaşılmıştır. Sağlık Bakanlığı bünyesinde yapılan bu alt yapı çalışmalarının hastane düzeyinde yapılandırılması katılımcıların verdikleri cevaplara bakıldığında yapılabilirliğinin yüksek olduğu söylenebilir. Bulut sistemlere her bir hastanenin kendisine verilen yetki ile erişim sağlayıp çeşitli işlemler gerçekleştirmeleri mümkün olabilir. Bulut sistemlerin ilk adım olarak Bakanlık düzeyinde yapılandırılması, bilgi sistemleri noktasında entegrasyon ve güvenlik problemine iyi bir çözüm olabileceği Katılımcı 1'in görüşlerine bakılarak ifade edilebilir. Katılımc1 4 ise bulut sistemlerin hastane düzeyinde yapılandırılmasının gizlilik ve güvenliğe ilişkin problemlere sebep olacağını ifade etmiştir. Katılımcı 3, 8, 9 ve 10'un ifadelerine bakıldığında bulut sistemlerin Bakanlık düzeyinde alt yapısının güçlendirilip bu sisteme erişimin hastane düzeyinde sağlanmasından sonra hastane yönetiminin tedarik ettiği mobil teknolojileri sisteme entegre etmesi gerektiği belirtilmiştir. Ayrıca Katılımcı 5 ve 7, hastanede tüm süreçlerin bulut bilişim alt yapısına dâhil edilmesi gerektiğini ve süreçlerde bütünlük sağlanması adına bunun önemli bir iş olduğunu vurgulamışlardır. Bulut sistemlerin uygulanmasına ve sağlık sistemi üzerindeki etkisinin ölçülmesine yönelik Katılımcı 6, bulut sistemlerin uygulanması için Sağlı Bakanlığı'nın pilot alanlar seçip uygulamanın sonuçlarını ölçmesinin gerekliliğini ifade etmiştir.

iv. Sağlık hizmetinin sunumu ile ilgili veri bulut bilişim teknolojilerinde depolanabilir mi, bunun için nasıl bir yapı oluşturulmalıdır?

Sağlık hizmetlerine ilişkin olarak hasta bilgilerinin bulut sistemlerde depolanmasına ilişkin katılımcıların çoğunun fikir birliği içerisinde olduğunu söylemek mümkündür. Katılımcıların altısı konuyla ilgili olarak olumlu bir yaklaşım sergilerken katılımcıların dördünün bu konuda olumsuz düşünceye sahip oldukları anlaşılmaktadır. Konuya ilişkin verilen cevaplar incelendiğinde Katılımcı 1'in görüssleri oldukça dikkat çekicidir. Söz konusu katılımcı, hastaya ilişkin bilgilerin hastane düzeyinde ilgili kişilerin erişimine açık olması gerektiği ve bunun yapılması gerektiğini öne sürmüştür. Sağlık hizmetlerinde çok yoğun veri olduğunu ve bu verilerin bulut sistemlerde erişime açık bir şekilde bulundurulmasını sağlık hizmetlerinin daha etkili sunumu için oldukça önemli olarak görmektedir. Buna paralel olarak Katılımc 3, hastaya ait bilgilerin Bakanlık düzeyinde kaydedilmesi gerektiğini ifade ederek yetki ve sorumluluğun Bakanlıkta olması gerektiğini vurgulamıştır. Buna ek olarak Katılımcı 7, hastaların bilgilerinin gizlilik ve güvenliklerinin sağlanması için yazılımların güçlendirilmesi ve bilgi sistemi alt yapısının sağlamlaştırılması gerektiğini ifade etmiştir. Hukuki alt yapısının sağlam bir zeminde oluşturulması gerekliliği katılımcıların çoğunluğu tarafından belirtilmiştir. Diğer yandan hastaya ilişkin bilgilerin bulut sistemlerde depolanmasına ilişkin olumsuz görüş belirten katılımcılar ise
Katılımcı 2, 5, 8 ve 9'dur. Bu katılımcılar hastaya ilişkin bilgilerin bulut sistemlerde depolanmasının çeşitli problemler oluşturacağına yönelik görüş bildirmiştir. Bilgilerin gizlilik ve güvenliğinin sağlanması konusunda alt yapıya ilişkin çeşitli kısıtlar bulunduğu görüşü benimsenmiştir. Bu nedenle katılımcıların çoğu hukuki alt yapının oluşturulmasının öncelikli olarak yerine getirilmesi gereken bir iş olduğunu ifade etmişlerdir.

\section{v. Bulut bilişim sistemlerine yapılan yatırımlar sonucunda sağlık hizmetleri elde bulunan personel ile sürdürülebilir mi?}

Hastanenin bulut bilişim sistemlerine geçmesinden sonra elde bulunan personel ile bu sistemleri çalıştırma ve yönetmenin mümkün olmadığı Katılımcı 7 ve 10 hariç tüm katılımcılar tarafından belirtilen bir görüş olmuştur. Katılımcıların sekizi bulut sistemlere geçildiğinde, teknik özelliğe sahip ve yeni olan bu işin hastanede bulunan teknik personelle sürdürülebilmesinin mümkün olmadığını vurgulamışlardır. Yapılan yatırımlar sonucunda teknik işler noktasında donanımlı insan faktörünün tedarik edilmesi gerekliliği ifade edilmiştir. Benimsenen bu yaygın görüş, hastanede mevcut çalışan teknik personelin şimdiki sistemin teknik işlerini yerine getirebildiğini vurgulamaktadır. Yeni bir siteme geçilmesi ve teknik noktada yeni yatırımların yapılmas1, bu alanda yetkin personele ihtiyac1 ortaya koyacaktır. Yetkin personelin istihdam edilmesi gerekliliğine vurgu yapıldıktan sonra elde bulunan personelin bu işlerde istihdamı mümkün ise, eğitim yolu ile çalışanların bulut sistemleri kullanma noktasında yetkin olmaları sağlanabilir. Bu düşünceyi ifade eden Katılımc1 1 ve 3, hastane içerisinde bu sistemleri kullanma yetisinin kazandırılması için eğitimin önemini vurgulamıştır. Diğer yandan Katılımcı 2 hasta mahremiyetine ilişkin görüş beyan etmiştir. $\mathrm{Bu}$ ifade hasta bilgilerinin gizlilik ve güvenliği ile çok yakından ilişkilidir. Sağlık yöneticilerinin hasta mahremiyeti konusunu benimsemesi ve bunun bilincinde olan teknik personelin istihdam edilmesi gerektiğini açıkça ifade etmeleri oldukça dikkat çekicidir. Bulut bilişim hizmetlerinin sağlık hizmetleri ve özellikle de hasta bilgilerinin yönetimi ile yakından ilişkili olmasından ötürü, bu hizmetleri yerine getirecek olan personelin tedarik edilmesi gerektiği ve elde personel bulunuyorsa eğitim yoluyla nitelik açısından kalitenin sağlanması yaygın olarak benimsenmiştir.

vi. Bulut bilişim altyapısı oluşturulduktan sonra hastanede veri yönetim biriminin kurulmasına ihtiyaç bulunmaktadır. Veri yönetim birimi hizmetlerinin yapılması için veri yönetim personeline ihtiyaç var mı?

Bulut bilişim alt yapısı oluşturulduktan sonra hastane düzeyinde veri yönetim biriminin kurulması gerekmektedir. Elde bulunan personelle veri yönetim biriminin işleyişinin mümkün olup olmadığına ilișkin soruya verilen cevaplar, katılımciların tamamının elde bulunan teknik personelin mevcut teknik görevleri yerine getirebildiğini, bulut bilişim alt yap1s1 oluşturulduktan sonra hasta bilgilerinin yönetimin sağlanması için personel tedarik edilmesi gerektiğini belirttiği görülmektedir. Katılımcıların tamamı, kalifiye personelin tedarik edilmesi gerektiğini belirtmişlerdir. Diğer katılımcılara paralel görüş belirten Katılımcı 3, bilimsel çalışmaların önemine vurgu yapmıştır. Bilimsel çalışmalara kaynaklık etmesi bakımından verilerin iyi yönetilmesi ve istenildiği zaman erişime açık bulundurulmasının önemine 
ilișkin nitelikli personele dikkat çekmiștir. Katılımcıların tamamı nitelik açısından uygun personelin tedarik edilmesi gerektiğini ifade etmiştir. Bu durum bulut sistemler ve veri yönetimi alanında eğitim almış olan personelin önemini açıkça ortaya koymaktadır.

\section{vii. Mobil iletişim teknolojileri ile hangi tür hasta profiline sağlık hizmeti sunulabilir?}

Mobil iletişim teknolojileri ile hangi hasta profiline sağlık hizmeti sunulabileceğine ilişkin olarak katılımcıların çoğunluğu benzer görüşler ifade etmiştir. Buna göre, mobil iletişim teknolojilerinin sağlık hizmetlerinin her aşamasında kullanılmasının mümkün olduğu söylenebilir. Tanı, teşhis, tedavi ve tedavi sonrası bakım ve izlemlerde mobil teknolojiler etkili araçlar olarak kullanılabilir. Katılımcı 1'in bu konudaki ifadeleri oldukça açıklayıcıdır. Nitekim Katılımc1 1, bütün hasta profili için bu teknolojilerin kullanımının uygun olduğunu beyan ederek özellikle kronik hastalığı olanların izleminde etkili olacağını belirtmiştir. Gerek ayaktan ve gerekse yatan hastaların çeşitli teknolojilerin entegre edilip kullanılması ile hayati bulgularının izleminde ve tedaviye ilişkin bakım planlarının oluşturulmasında kullanılabileceğini beyan etmiştir. Ayrıca uzun dönemli bakıma ihtiyacı olan hastaların sağlık durumlarının izleminde etkili olarak kullanılabileceğini de ifade etmiştir. Katılımcı 2, ayrıca mobil teknolojilerin sosyokültürel açıdan orta ve yüksek düzeyde bulunan hastalara sağlık hizmeti sunumu için kullanılmasının daha isabetli olduğunu belirtmiştir. Buna ek olarak, mobil teknolojilerin sağlık hizmetlerinin sunumu için kullanılmasını bir strateji olarak değerlendirip bu stratejinin başarıya ulaşmasında eğitim düzeyi ve kültür gibi faktörlerin çok önemli bir yere sahip olduğunu belirtmiştir. $\mathrm{Bu}$ durum oldukça önemlidir. Hizmetin sunulacağ veya belli bir yaşın üzerinde ve teknoloji okur-yazarlık seviyeleri düşük ise hizmetin sunumunda kisıtlar oluşabileceği söylenebilir. Diğer yandan Katılımcı 8 ve 9, katılımcıların çoğunluğunun aksine mobil teknolojilerin hasta bilgilendirme ve eğitim dışında kullanılmasının uygun olmadığı görüşünü ileri sürmüşlerdir.

viii. Mobil iletişim teknolojileri hastane içi ve dışı sağlık hizmetlerinin sunumu için nasıl kullanılabilir?

Mobil iletişim teknolojilerinin hastane içi ve dişı sağlık hizmetlerinde kullanılabilirliğinin değerlendirildiği katılımcı görüşleri incelendiğinde, mobil teknolojilerin kullanılabilir olduğunun tüm katılımcılar tarafından benimsenen bir görüş olduğu anlaşılabilecektir. Katılımcıların tümünün gerek sağlık kurumunda ve gerekse de sağlık kurumu dışında mobil teknolojilerin kullanımına olumlu yaklaştıkları görülmektedir. $\mathrm{Bu}$ görüşlere dayanılarak hastane içerisinde tüm süreçlerde bu teknolojilerin kullanılabileceği belirtilmiştir. Acil, klinik ve polikliniklerde, hasta izleminde, order verilmesi gibi hizmetlerin sunumunda mobil teknolojilerin kullanılabileceği ifade edilebilir. Buna yönelik Katılımcı 6, durumudaha geniş bir perspektifle ele almıştır. Buna göre, hastanın randevu almasından taburcu olana kadar etkili olarak kullanılabileceği belirtilmiştir. Buna ek olarak mobil teknoloji kullanımının sadece sağlık kurumu ile sınırlı olmadığı aynı zamanda evde sağlık hizmetleri ve uzun dönemli bakıma ihtiyacı olanların hayati bulgularının izlemi ve tedavi planlarının oluşturulması için kullanılabileceği Katılımc1 1 ve 7 tarafindan ileri sürülmüştür. Mobil teknolojilerin sağlık hizmetlerinde kullanımının hastalar için de çok faydalı olduğu üzerinde durulmuştur. Hasta, randevu almada kolaylık elde edecek, kendi sağlık bilgilerine istediğinde erişim sağlayabilecek, laboratuvar, MR, röntgen vb. sonuçlarına erişim sağlayabilecektir. Diğer yandan mobil teknolojilerin hekimler açısından da çok faydalı olduğu belirtilmiştir. Hekimler arası iletişim kolaylaşacak, konsültasyon işlemleri hızlanacak ve nihayetinde sağlık hizmetinin sunumu daha hızlı bir şekilde gerçekleştirilmiş olacaktır. Katılımcı 2, bu durumun sağlanmasından sonra, sağlı hizmetinin marjinal faydasının artacağını ileri sürmüştür ve mobil teknoloji alt yapısı ile sunulan sağlık hizmeti sonucu hastaların sağlık hizmetlerinden aldığı fayda ve memnuniyet düzeylerinin artacağını vurgulamıştır. Bu durum oldukça önemlidir. Daha değerli sağlik hizmeti üretiminde mobil teknoloji kullanımının etkili bir araç olarak değerlendirilmesi oldukça dikkat çekicidir. Hastane dışında da bu teknolojilerin kullanılabileceği yaygın olarak benimsenmiştir. Evde sağlık hizmetlerinde, ambulans hizmetlerinde ve evde yatan ve ayaktan hastaların izleminde, hayati bulgularının değerlendirilmesi için kullanılabileceği belirtilmiştir. Son olarak Katılımc1 1'in ifadesine de değinmek faydalı olacaktır. Katılımcı 1, hekim tarafından bilgiye erişimin hızlıca sağlanmasını büyük bir avantaj olarak değerlendirmektedir. Hasta sayısına bağlı olarak bilgi yoğunluğunun fazla olması bilgiye erişime ilişkin hızın önemini açıkça ortaya koymaktadır. Hekimin kendi hastasına ilişkin bilgilere her yerden erişim sağlayabilmesi sağlık hizmetlerinin kesintisiz sunulması için oldukça önemlidir.

ix. Ayaktan ve yatan hastaların takibinde mobil sağlık hizmetlerinden nasıl yararlanılabilir?

Mobil sağlık hizmetleri ile ayaktan ve yatan hastalara sağlık hizmetinin sunulabileceği veya hizmet sunumunun kolaylaşacağ1 konusunda tüm katılımcılar olumlu görüş belirtmektedir. Katılımcılar, mobil cihazların ayaktan ve yatan hastalar için kullanılabilecek bir araç olduğu üzerinde fikir birliği içerisindedir. Mobil sağlık hizmetlerinin sağlık kurumu ve hasta aynı şekilde hekim ve hasta arasında iletişimi iyileştireceği kabul edilmiştir. Hekim ve hasta arasındaki iletişimin kolaylaşacağı, hastanın izleminin ve vital bulgularının izleminde önemli gelişmelerin kaydedileceği ve işlemlerin daha hızlı görüleceği düşüncesi yaygın olarak kabul edilmiştir. Ayrıca hasta, mobil sağlık uygulamalarına kendi akıllı cihazı ile erişim sağlayarak kendi sağlık geçmişini görüntüleyebilecek, çeşitli tahlil, tetkik ve laboratuvar, röntgen sonuçlarına ilişkin dokümanlara ulaşabilecektir. $\mathrm{Bu}$ durumun hastanın daha bilinçli hale getirilmesinde önemli bir gelişme olduğu belirtilmiştir. Uygulamaların, hastanın sağlık kurumundan randevu alması, tedavi süreci ve tedavi süreci sonrasında kişinin hayati bulgularının izleminde etkili olarak kullanılabileceği ifade edilmiştir. Genel durumlarda mobil sağlığın sağladığı faydalar oldukça fazla olmakla birlikte Katılımcı 1 acil durumlarda da bu imkânlardan faydalanılabileceğini belirtmiştir. Acil durumlar risk ve belirsizlik içerdiğinden hastanın hastaneye transferi boyunca hayati bulgularının ilgili hastaneye aktarılmasında ve acil personelinin buna yönelik hazırlık yapması önemli bir gelişme olarak belirtilmiştir.

x. İlaç orderlarının formalleşmesi ve tıbbi hataların
önlenmesinde mobil iletişim teknolojileri nasıl
kullanılabilir?


Orderlar sağlık hizmetinin sunumunda klinik hizmetlerde oldukça önemli bir konudur. Hekim ile hemşire arasında orderların formal bir nitelik kazanması, tüm katılımcılar tarafından gerekli bir durum olarak kabul edilmiştir. Tüm katılımcılar, tıbbi müdahaleye esas oluşturan ilaç orderlarının standardize edilmesi gerektiğine inanmaktadır. İletişimin daha etkin ve hızlı olması, müdahalenin zamanında yapılması, hekim ve hemşire arasında iletişim mekanizmasının gelişmesi, oluşabilecek tıbbi hatalarda sorumluluğun hangi tarafta olduğunun belirlenmesi açısından önemli olduğu çeşitli katılımcılar tarafından belirtilmiştir. Sağlık hizmetlerinde orderların geleneksel yapısı olan sözlü orderların sağllk kurumu bünyesinde bir mobil uygulama kullanılarak formalleşmesi gerekmektedir. Buna yönelik Katılımc1 10, ortak bir mobil uygulamanın geliştirilmesi gerektiği ve bunun hastane bilgi sistemi ile entegre edilerek sağlık hizmetini direkt olarak sunan sağlik personelinin sisteme kaydedilmesi gerektiğini belirtmiştir. $\mathrm{Bu}$ durum entegrasyon ve yetki problemine bir çözüm niteliğinde olup dikkate alınması gereken bir konudur.

\section{xi. Sağlık Bakanlığının başlattığı e-Nabız program sağlık hizmetlerini nasıl etkiler?}

e-Nabız programı, Sağlık Bakanlığı'nın hastanın sağlık hizmetlerinde güçlendirilmesi gerektiğine ilişkin anlayışını ortaya koymaktadır. Hasta, geleneksel sağlık hizmetlerinde daha pasif durumda iken bu ve buna benzeri programlar ile birlikte hasta kendi sağlık durumuna ilișkin bilgi sahibidir. Hastanın, elektronik sağlık kaydı ve kişisel sağlık kaydı yönetimi konularında güçlendirilmesi gerektiği konusu son zamanlarda oldukça önemlidir. Katılımcıların e-Nabız ile ilgili görüşleri incelendiğinde; katılımcıların çoğunluğunun bu gelişmeden haberdar olduğu ve sağlık hizmetlerinde kullanılabilirliğine ilişkin olumlu görüş beyan ettikleri anlaşılmıştır. Katılımcıların çoğu bu programın, sağlık hizmetlerinde önemli değişiklikler yapacağını ve hasta ve sağlık kurumu açsından büyük kolaylık sağlayabileceğini belirtmiştir. Belirtilen tüm olumlu görüşlere ek olarak Katılımcı 1'in, sağlık hizmetlerinde yeni bir devrin başlayacağına işaret etmesi oldukça önemlidir. Nitekim, sağlık hizmetleri sunumunun geleneksel yapısında çok önemli değişiklikler yaşanmaktadır. e-Nabız'ın hastaların ulaşım ve sağlık hizmetine erişim gibi konularda işini kolaylaştıracağ 1 Katılımcı 1, 2 ve 4 tarafından ifade edilmiştir. Sağlık hizmetine erişim sağlamak için merkezi hekim randevu sistemi kullanımının önemli olduğu belirtilmiştir. $\mathrm{Bu}$ anlamda hastanın önemli avantajlar elde ettiği belirtilmiştir. Tüm bu gelişmelere ilişsin olumlu ifadelere karşılık, Katılımcı 3, 8 ve 9 e- Nabız'a ilişkin olumsuz görüş belirtmiştir. Katılımcı 3 , bilgi güvenliğine ilişkin kaygısını ifade etmiştir. Hastaya ait bilgilerin mobil cihazlar üzerinden görüntülenmesinin çeşitli riskler içerdiğini vurgulamıştır. $\mathrm{Bu}$ oldukça dikkat edilmesi gerekli bir husustur. Çünkü hasta bilgilerine yetkisiz kişilerin de erişim sağlaması sistemi tehlikeye atabilme ihtimalini içermektedir. Diğer yandan ise Katılımcı 8 ve 9, e-Nabız programının sağlık hizmetlerini etkilemeyeceğini belirtmişlerdir.

xii. Facebook, Twitter, Periscope, Skype vb. sosyal medya uygulamaları sağlık hizmetlerinde nasıl kullanılabilir?

İnternet üzerinden sosyal medya uygulamalarına erişim ile çeşitli kişi ve kurumlar takip edilebilmektedir. Bu nedenle bu platformlar üzerinden halkın dikkatini hayati konulara çekmek oldukça faydalı olabilmektedir. Katılımcıların buna ilişkin görüşlerine bakıldığında, özellikle koruyucu sağlık hizmetlerinde ve halk sağlığı bilincinin oluşturulması için kullanılabileceği hemen hemen tüm katılımcılar tarafından benimsenmiştir. Özellikle bazı konularda farkındalık yaratma, bilinç oluşturma ve toplumun sağlı düzeyinin iyileştirilmesi noktalarında faydalı olacağı belirtilmiştir. Söz konusu uygulamaları kullananlar hali hazırda çok geniş bir kitle olmasından ötürü hayati konularda çok fazla kişiye ulaşılması sağlanabilecektir. Belirtilen tüm bu görüşlere ek olarak Katılımcı 2 tarafından, bu tür uygulamaların sağlık kurumu bünyesindeki sağlık çalışanları arasındaki iletişimi geliştireceği vurgusu yapılmıştır. Bu sistemin çalışması için gerekli olan kişilerin sisteme kaydedilmeleri ile bu kişiler arasında koordinasyon yaratılması sağlanabilir.

xiii. Mobil sağlık uygulamalarının sağlık hizmeti sunumunda kullanımı hastanenin katlandığı işlem maliyetlerini nasıl etkiler?

Hastane dişında gerçekleşen lojistik hizmetlerde sipariş, tedarik, teslim ve depolama süreçlerinde birtakım işlemler oluşmaktadır. $\mathrm{Bu}$ süreçlerde mobil sağlık uygulama kullanılmasının işlem maliyetlerini nasıl etkileyeceğine yönelik katılımcıların görüşleri incelendiğinde, tüm katılımcıların mobil iletişim teknolojilerinin işlem maliyetlerini düşüreceğine inandıkları anlaşılmaktadır. Bütün katılımcılar mobil iletişim teknolojilerinin lojistik hizmetlerde kullanımını olumlu ve faydalı bulmaktadır. Hatta Katılımcı 8 ve 9, mobil iletişim teknolojilerinin işlem maliyetlerini azaltacağını vurgulamıştır. Mobil iletişim teknolojilerinin işlem maliyetlerini düşüreceği noktasında tam bir fikir birliği vardır ancak kısa vadede teknolojik alt yapıya yapılan yatırımların maliyetleri ve işlem maliyetlerini arttıracağı belirtilmiştir. Gerekli sistem alt yapısı oluşturulduktan sonra işlem maliyetlerinin azalacağı belirtilmiștir. Bu imkânları sunabilen akıllı cihazların olması ve bunların daha fonksiyonel bir hale getirilmesi oldukça önemlidir.

\section{xiv. Mobil iletişim teknolojileri hastanede hangi} süreçler için kullanılabilir (idari)?

Mobil iletişim teknolojilerinin hastane içerisinde iş süreçlerinde kullanılabileceği tüm katılımcılar tarafından ifade edilmiştir. İdari işlerde; e-imza, bilgi paylaşımı, toplantıların planlanması ve koordine edilmesi vb. çok çeşitli işlerin gerçekleştirilmesinde oldukça kullanışlı olduğu belirtilmiștir. Ayrıca, konsültasyon ișlemlerinde de kullanılabileceği Katılımcı 1 tarafından belirtilmiştir. Sağlık çalışanları arasında iletişimi kolaylaştırması açısından da mobil teknolojilerin faydalı olduğu Katılımcı 1, 3, 6, 8, 9 ve 10 tarafından belirtilmiştir. Ayrıca Katılımcı 7, personel takibi, nöbetler, temizlik ve arıza takibi, lojistik hizmetleri gibi idari ișlerde mobil teknolojilerin kolayllkla kullanılabileceğini ifade etmiştir.

xv. Mobil iletişim teknolojileri lojistik hizmetlerde (sipariş, tedarik, teslim, depolama) hangi süreçlerde ve nasıl kullanılabilir?

İşlem maliyetlerinin temeli olan lojistik hizmetlerde mobil iletişim teknolojilerinin kullanılabilir olduğu ve kullanılması gerektiği bütün katılımcılar tarafından ifade edilmiştir. Bütün katılımcılar lojistik hizmetlerde mobil teknoloji kullanımının sistemi rahatlatacağını belirtmiştir. 
Lojistik hizmetlerde veya sipariş, teslim, depolama, stok kontrol ve depodan çıkış yaparken bu teknolojilerin etkili bir şekilde kullanılabileceği belirtilmiştir. $\mathrm{Bu}$ süreçleri ayırt etmeden süreçlerin tamamında mobil teknolojilerin kullanılabileceği ileri sürülmüştür. Mobil teknolojilerin lojistik hizmetlerde kullanımına ilişkin Katılımc1 5, 6, 7, 8 ve 9 çalışacak sistemin alt yapısına vurgu yapmıştır. Buna göre, hastanenin muhasebe sistemine entegre edilecek ak1llı cihazlar ile bu işlemleri gerçekleştirmenin kolay, hızlı ve etkili olacağı ifade edilmiştir. Ayrıca Katılımcı 3 ise, diğer katılımcılara benzer görüş beyan etmesine ek olarak mobil teknolojilerin stok yönetiminde nasıl kullanılacağını da eklemiştir. Sisteme entegre edilen akıllı cihazlar ile teslimi yaklaşan veya kritik düzeye düşen malzemelerin bilgisinin ilgili kişiye kısa mesaj ile iletilmesini sağlamanın hizmetlerde aksamayı önleme noktasında faydalı olacağını belirtmektedir.

\section{Tartışma ve Sonuç}

Mobil sağlık uygulamaları, son birkaç yıldır oldukça hızlı gelişim göstermektedir. Tüm sektörlerde olduğu gibi sağlık sektöründe de oldukça fazla kullanılan bu teknolojilerin daha farklı amaçlar için kullanılabileceği sağlık sektörünün paydaşları tarafından değerlendirilmektedir ve bu amaca yönelik pilot projeler ile çeşitli bulgulara ulaşılmaya çalışılmaktadır. Bu çalışmada, mobil sağlık uygulamalarının hastanelerde kullanılabilirliği araştırılmıştır. Çalışmada nitel araştırma yöntemi kullanılmıştır. Alan araştırması bir kamu hastanesinde çalışan üst ve orta kademe yöneticileri ile gerçekleştirilmiştir. Mobil teknolojilerin hastane düzeyinde yapılandırılması, mobil sağlık sistemi için en önemli adımı oluşturmaktadır. Mobil iletişim teknolojilerinin hastane bilgi yönetim sistemi ile çalışabilir olup olmadı̆̆ konusunda yöneticilerin tamamı hemfikirdir ve bunun kolay ve mümkün olduğunu ileri sürmüşlerdir. Söz konusu teknolojiler hastane bilgi yönetim sistemi ile uygun yazılımlar geliştirilerek entegre edilebilir ve kolayca kullanılabilir. Söz konusu uygulamaların sisteme entegre edilerek ve diğer gerekli birtakım tedbirlerin alınması sonrasında ise etkili bir araç olarak kullanılabileceği anlaşılmıştır. Dolayısıyla mobil sağlık uygulamalarının hastanelerde kullanılabilir bir araç olduğu saptanmıştır.

Mobil sağlık uygulamalarının sağlık kurumlarında işlemlerin azaltılmasına ve süreçlerin iyileștirilmesine katkı sağlayacağı düşünülmektedir. Sırada bekleme sürelerinin azaltılması ve hizmetin sunumunun niteliğinin arttırılması ile ilgili tasarlanıp geliştirilecek mobil uygulamalar sağlık alanına katkı sağlayabilecek olup maliyetlerin kontrolü ve hastaları karşılayan personelin aşırı iş yükünün getirmiş olduğu zaman kısıtından kurtulmayı sağlayabilecektir. Aşırı iş yükünden doğan işlemlerin ve bununla direkt bağlantılı işlem maliyetlerinin kontrolü ve minimizasyonu noktasında mobil sağlık uygulamalarının sağlık hizmetleri endüstrisinin son trendleri arasında olduğu söylenebilir. Çalışma sonucunda geliştirilen öneriler aşağıda sıralanmıştır.

Sağlık hizmetlerinin bulut sistemler üzerinden sunulması için bulut sistemlerin teknik alt yapısının güçlü yazılımlar ile geliştirilmesi ve konuya ilişkin hukuki alt yapının da çok kapsamlı bir şekilde oluşturulması gerekmektedir. Bulut sistemlerde yetki ve sorumluluğun kimde/kimlerde olacağ1, kimin hangi bilgiye ne kadar erişebileceği konusunun detaylı bir şekilde belirlenmesi gerekmektedir.
Mobil teknolojiler sağlık çalışanlarını mobilize ettiği gibi hastaları da mobilize etmektedir. Hasta bu sayede sadece belli bir hastaneye bağımlı olarak kalmaz, kendi sağlık durumuna ilişkin bilgileri istediği hekim ile paylaşma gücünü elde eder. Bu teknolojiler özellikle uzun dönemli hasta bakımı açısından son derece önemsenmektedir ve ülkemizde de bu imkânlardan yararlanılmalıdır.

Hastanın sağlık bilgilerinin her an erişime açık hale getirilmesi güvenlik riskleri içermektedir. $\mathrm{Bu}$ durum sağlık hizmetlerini olumsuz etkileyebilir. Sistemin sağlıklı bir şekilde yürümesi için hasta bilgilerinin mahremiyetine önem verilmeli ve gerekli ihtiyati tedbirler alınmalıdır.

Toplumun farkındalık kazanması, bilinç düzeyinin arttırılması ve davranış değişikliğinin oluşturulması için bu mobil iletişim teknolojileri etkili bir araç olarak kullanılabilir.

Mobil sağlık uygulamalarının sağlık hizmetlerinde etkili bir araç olarak kullanılabilirliği karar vericiler tarafından değerlendirilmelidir.

Mobil sağlık uygulamalarının Türkiye'de neden geç başladığı ve daha etkin nasıl uygulanabileceğine ilişkin gelecekte yapılacak araştırmalar alana daha fazla katkı sağlayacaktır.

\section{Teşekkür}

$\mathrm{Bu}$ çalışmanın her aşamasında çok büyük emekleri olan başta danışmanım Yrd. Doç. Dr. Elif Türkan ARSLAN olmak üzere, bölüm başkanımız Doç. Dr. Levent B. KIDAK'a ve Doç. Dr. Serhat BURMAOĞLU'na katkılarından dolayı çok teşekkür ediyorum.

\section{Kaynaklar}

Ağaç, F. (2015). Mobil Uygulamalar Sağlık Sistemini Kişiselleştiriyor, http://www.bilisimdergisi.org/s174/pdf/4251.pdf, Erişim Tarihi: 8.8.2015.

Ağırbaş, İ. (2016). Hastane Yönetimi ve Organizasyon. Siyasal Kitabevi, Ankara.

Akgemci, T. ve Güleş, H. K. (2010). İşletmelerde Stratejik Yönetim. İkinci Baskı, Gazi Kitabevi, Ankara.

Al-Hadithy, N., ve Ghosh, S. (2013), "Smartphones And The Plastic Surgeon", Journal Of Plastic, Reconstructive \& Aesthetic Surgery, 66(6), E155E161.Doi:Http://Dx.Doi.Org/10.1016/J.Bjps.2013.02.014.

Arthur, B. (2011). Teknolojinin Doğası. İdil Çetin (Çev.), Optimist Yayınları, İstanbul.

Basalla, G. (2013). Teknolojinin Evrimi. Soydemir, C. (Çev.), Doğu Batı Yayınları, Ankara.

Bellman, S., Potter, R. F., Hassard, S. T., Robinson, J. A. ve Varan, D. (2011), "The Effectiveness of Branded Mobile Phone Apps", Journal of Interactive Marketing, 191-200.

Burke, L. E., M. A. Styn, S. M. Sereika, M. B. Conroy, L. Ye, K. Glanz, M. A. Sevick ve L. J. Ewing (2012), "Using MhealthTechnology to Enhance SelfMonitoringForWeightLoss: A Randomized Trial", Am J PrevMed, 43(1), 20-26.

Coye, M. J. ve Kell, J. (2006), "How HospitalsConfront New Technology", Health Affairs, 25, 163-173.

Djellal, F. ve Gallouj, F. (2007), "Innovation In Hospitals: A Survey of The Literature", European Journal of Health Economics, 8(3), 181-193. 
Drucker, P. (2013). Büyük Değişimler Çağında Yönetim. İkinci Baskı, Dicleli, Z. (Çev.), Optimist Yayınları, İstanbul.

Enginoğlu, D. (2015). İnovasyon Yönetimi ve AR-GE. Nobel Yayınları, Ankara.

Esatoğlu, A. E., Ağırbaş, İ., Payziner, P. D., Akbulut, Y., Göktaş, B., Özatkan, Y., Uğurluoğlu, E., Yıldırım, Törüner, M., Gök, H., Atasoy, K. Ç., Çakır, S. Ü. ve Ökten, İ. (2010), “Ankara Üniversitesi Tıp Fakültesi Hastaneleri’nde Maliyet Analizi”, Ankara Üniversitesi Tıp FakültesiMecmuası, 63(1), 17-27.

Franco, M. ve Tursunbayeva, A. (2014), "Mobile Technology and Public Health OrganisationalSystem", EmergentIssues in Management, 1, 80-89.

Gartner (2009). eHealthfor a Healthier Europe, http://www.ticsalut.cat/flashticsalut/pdf/246_2_ehealthforahe althiereurope.pdf. Erişim Tarihi: 25.9.2016.

Güler, E. ve Eby, G. (2015), "Akıllı Ekranlarda Mobil Sağlık Uygulamaları”, Eğitim ve Öğretim Araştırmaları Dergisi, 4(3), 45-51

Gürbüz, S. ve Şahin, F. (2014). Sosyal Bilimlerde Araştırma Yöntemleri. Seçkin Yayıncılık, Ankara.

Işık A. H. ve Güler, G. (2010), "Teletıpta Mobil Uygulama Çalışması ve Mobil İletişim Teknolojilerinin Analizi”, Bilişim Teknolojileri Dergisi, 3(1), 1-10.

Kamsu-Foguem, B. ve Foguem, C. (2014), "Telemedicine and Mobile Health WithIntegrativeMedicine In DevelopingCountries", Health Policy and Technology, 3(4), 264-271. Doi:10.1016/J.Hlpt.2014.08.008

Kavuncubaşı, Ş. ve Yıldırım, S. (2012). Hastane ve Sağlık Kurumları Yönetimi. Siyasal Kitabevi, Ankara.

Kılıç, S. (2016). İnovasyon ve İnovasyon Yönetimi. İkinci Baskı, Seçkin Yayınları, Ankara.

Kumar, S.,Nilsen, W. J., Abernethy, A., Atienza A., Patrick, K. ve Pavel, M. (2013), "Mobile Health Technology Evaluation: The mHealthEvidence Workshop", Am J PrevMed, 45(2), 228-36.

Liu, C., Q. Zhu, K. A. Holroyd ve Seng, E. K. (2011), "Status and Trends of Mobile-Health Applications ForİosDevices: A Developer'sPerspective", Journal of Systems and Software, 84(11), 2022-2033

Luxton, D. D.,Hansen, R. N. ve Stanfill, K. (2014), "Mobile App Self-CareVersus In-Office Car Efor Stress Reduction: A CostMinimization Analysis", Journal of Telemedicine andTelecare, 20(8), 431-435.

Mather, C.,Cummings, E., Allen, P. (2014), 'Nurses' Use of Mobile Devices To Access Information In Health CareEnvironments In Australia: A Survey Of UndergraduateStudents", JmirMhealth and Uhealth, 2(4), 110 .

Nakamura, N.,Koga, T. ve Iseki, H. (2014), “A MetaAnalysis of Remote Patient Monitoring For Chronic Heart Failure Patients", Journal of Telemedicine and Telecare, 20(1), 11-17.

Patrick, K.,Griswold, W. G., Raab, F. ve Intille, S. I. (2008), "Health and The Mobile Phone, Am J PrevMed", 35(2), 177-181.

Pope, C.,Halford, S., Turnbull, J. ve Prichard, J. (2014), "Cyborg Practices: Call-Handlers And Computerised
Decision Support Systems In Urgent and Emergency Care", Health InformaticsJournal, 20(2), 118-126.

Sağlık İstatistik Yıllığı (2013). Sağlık İstatistikleri Yıllığı 2013 Haber Bülteni, http://www.tkhk.gov.tr/Dosyalar/da9700370c2c452dbaca5af9 ea973e58.pdf, Erişim Tarihi: 7.6.2015.

Seçim, H. (1991). Hastane Yönetimi ve Organizasyonu: Türkiye'de Hastanelerin Organizasyonu İçin Bir Model Önerisi, İstanbul Üniversitesi İşletme İktisadı Enstitüsü Yayınları, İstanbul.

Semple, J. L.,Sharpe, S., Murnaghan M. L., Theodoropoulos, J. ve Metcalfe, K, A. (2015), "Using A Mobile App For Monitoring Post-Operative Quality of Recovery of Patients At Home: A Feasibility Study", JmirMhealth and Uhealth, 3(1), 1-11.

Singh, A.,Wilkinson, S. ve Braganza, S. (2014), "Smartphones and PediatricApps To Mobilize The Medical Home", The Journal of Pediatrics, 165(3), 606-610.

Sloninsky, D. (2008). Towards The Development of An MhealthStrategy: A LiteratureReview, 1-62.

T.C. Sağlık Bakanlığı (1983). Yataklı Tedavi Kurumları İşletme Yönetmeliği, 13.1.1983 tarih ve 17927 mükerrer sayılı Resmi Gazete, Yapılan Değişiklikler İçin 05.05.2005 tarih ve 25806 sayılı Resmi Gazete, Ankara.

Tengilimoğlu, D., Işık, O. ve Akbolat, M. (2012). Sağlık İşletmeleri Yönetimi. Dördüncü Baskı, Nobel Yayın Dağıtım, Ankara.

Tezcan, C. (2016). Sağlığa Yenilikçi Bir Bakış Açısı: Mobil Sağl1k, Mart 2016, Yayın No: TÜSİAD-T/201603/575, 1-116

The Boston ConsultingGroup (2012). The Socio_EconomicImpact of Mobile Health. 1-50.

The Economist IntelligenceUnits (2015). Power To The Patient: How Mobile Technology isTransforming Healthcare.

Vélez, O.,Okyere, P. B., Kanter, A. S. ve Bakken, S. (2014), "A Usability Study of A Mobile Health Application For Rural Ghanaian Midwives", J Midwifery Womens Health, 59(2), 184-191.

Walcott, H. F. (1994). Transforming Qualitative Data: Description, Analysis and Interpretation. SAGE, London.

West, D. (2013). Improving Health Care Through Mobile Medical Devices and Sensors. Brookings Institution Policy Report, (October), 1-13, http://bioharness.com/media/WhitePapers/WhitePaper-ZWP010-West_Mobile Medical Devices_v06.pdf

Wragge, L. G. ve Co (2014). Connected Health White Paper,

$1-16$, http://blogimages.bloggen.be/zorgtechnologie/attach/260684. pdf, Erişim Tarihi: 10.10.2015.

Wu, R.,Appel, L., Morra, D., Lo, V., Kitto, S. ve Quan, S. (2014), "Short Message Service Or Disservice: Issues With Text Messaging In A Complex Medical Environment", InternationalJournal of Medical Informatics, 83(4), 278-284. Doi:Http://Dx.Doi.Org/10.1016/J.Ijmedinf.2014.01.003.

Wu, Y. P. ve Hommel, K. A. (2014), “Using Technology To Assess and Promote Adherence To Medical Regimens In Pediatric Chronic Illness", The Journal of Pediatrics, 164(4), 
922-927.

Doi:Http://Dx.Doi.Org/10.1016/J.Jpeds.2013.11.013

Yıldırım, A. ve Şimşek, H. (2013). Sosyal Bilimlerde

Nitel Araştırma Yöntemleri. Dokuzuncu Baskı, Seçkin

Yayınları, Ankara. 
